\title{
KAJIAN TENTANG LAMA FERMENTASI NIRA AREN (Arenga pinnata) TERHADAP KELIMPAHAN MIKROBA DAN KUALITAS ORGANOLEPTIK TUAK
}

\author{
Riska Mussa \\ Program Studi Pendidikan Biologi \\ E-mail: riska_mussa@yahoo.com
}

\begin{abstract}
Background: Nira palm (Arenga pinnata) is favored by the people because it can be consumed directly and processed for food. It is characteristic palm juice ( $A$. pinnata) can undergo fermentation because the sugar content is quite high and the presence of yeast in it. Therefore, this study examines the relationship between palm juice fermentation (A. pinnata) with the presence and abundance of microbial and organoleptic quality of wine.

Methods: The study was conducted on 2-5 June 2011 in the Basic Biology Laboratory Faculty of Teacher Training and Education Pattimura University.

Results: The abundance of yeast is more prevalent at the beginning of fermentation 0-5 hours, amounting to $27.1 \times 106$ to $48.8 \times 106$, while the number of bacteria over a lot of yeast in the fermentation time of 10 hours is $21.0 \times 106$, and after 15 hours, the amount of yeast and bacterial abundance due to a succession of diminishing the number of yeast $12.8 \times 106$ and $12.3 \times 106$ bacterial counts.

Conclusion: The result of organoleptic quality wine, the color of the indicator does not change while the best indicator of flavor found in the fermentation time 0 hours, and the aroma of the best indicators of the fermentation time of 15 hours.
\end{abstract}

Keywords: Abundance of microbes, Nira palm, Tuak

\begin{abstract}
Abstrak
Latar Belakang: Nira aren (Arenga pinnata) sangat digemari oleh masyarakat karena dapat dikonsumsi secara langsung dan diolah untuk kebutuhan pangan. Yang sangat khas adalah nira aren (A. pinnata) ini dapat mengalami fermentasi karena kandungan gula yang cukup tinggi dan kehadiran ragi di dalamnya. Oleh sebab itu, penelitian ini mengkaji hubungan lama fermentasi nira aren (A. pinnata) dengan kehadiran mikroba dan kelimpahannya serta kualitas organoleptik tuak.

Metode: Penelitian dilakukan pada tanggal 2-5 Juni 2011 di Laboratorium Biologi Dasar Fakultas Keguruan dan IImu Pendidikan Universitas Pattimura.

Hasil: Kelimpahan ragi lebih banyak terdapat pada awal fermentasi 0 - 5 jam yang berjumlah $27,1 \times 10^{6}$ $-48,8 \times 10^{6}$, sedangkan jumlah bakteri lebih banyak dari ragi pada waktu fermentasi 10 jam yaitu 21,0 $\times 10^{6}$, dan setelah 15 jam, jumlah kelimpahan ragi dan bakteri semakin berkurang karena mengalami suksesi dengan jumlah ragi 12,8 $\times 10^{6}$ dan jumlah bakteri $12,3 \times 10^{6}$.

Kesimpulan: Hasil uji kualitas organoleptik tuak, pada indikator warna tidak mengalami perubahan sedangkan indikator rasa yang terbaik terdapat pada waktu fermentasi 0 jam, dan indikator aroma yang terbaik pada waktu fermentasi 15 jam.
\end{abstract}

Kata Kunci: Kelimpahan mikroba, Nira Aren, Kualitas Organoleptik, Tuak 


\section{PENDAHULUAN}

Salah satu tumbuhan yang dimanfaatkan sebagai bahan pangan adalah aren (Arenga pinnata). Tumbuhan aren yang mirip pohon kelapa (Cocos nucifera) ini merupakan tanaman multifungsi, dengan seluruh bagian dari tumbuhan dapat dimanfaatkan untuk kelangsungan hidup manusia. Pohon aren merupakan salah satu tumbuhan penyeimbang ekosistem dan ekologi pedesaan. Fungsi pohon aren secara ekologis untuk melindungi sumber daya alam terutama tanah. Akar serabut pohon aren sangat kokoh, dalam, dan tersebar sehingga memiliki fungsi penting bagi penahan erosi tanah. Selain itu, akar aren juga memiliki kemampuan mengikat air, sehingga pohon aren bisa ditanam di daerah yang relatif kering dan tidak perlu perawatan intensif. Ini juga membantu kelestarian lingkungan hidup terutama untuk penghijauan pada daerah lereng pegunungan dan sungai-sungai. Pemanfaatan tumbuhan aren tidak hanya pada daun, buah serta batangnya, namun tanaman aren juga dapat menghasilkan nira yang memiliki nilai ekonomis tinggi. Nira pada dasarnya merupakan air yang keluar dari bunga aren atau kelapa. Nira adalah suatu minuman alami yang terasa manis karena mengandung glukosa. Kandungan glukosa pada nira menyebabkan nira banyak diolah sebagai gula tradisional oleh kebanyakan masyarakat di beberapa daerah (Hidayati, 2009).

Di Maluku, nira digunakan untuk membuat gula merah dan dijadikan minuman keras yang diolah dengan teknik destilasi tinggi untuk meningkatkan kandungan alkohol. Hasil fermentasi dari nira disebut tuak. Fermentasi nira menjadi tuak umumnya dilakukan selama sehari, dibantu ragi/khamir (Saccharomyces) dan bakteri misalnya Lactobacillus. Saccharomyces dapat menghasilkan etanol dan Lactobacillus menghasilkan asam selama fermentasi berlangsung. Jumlah sel ragi pada tuak adalah $10^{7}-10^{8} \mathrm{sel} / \mathrm{mL}$ sampel, sedangkan bakteri akan mengalami suksesi karena konsentrasi etanol meningkat (Mahulette, 2009a).

Menurut kebiasaan masyarakat, penggunaan nira yang baik yaitu beberapa saat setelah disadap dan tidak boleh dibiarkan bermalam, karena akan mengubah cita rasa. Berubahnya cita rasa ini disebabkan keberadaan bakteri yang mengubah gula menjadi asam. Perubahan ini juga diikuti dengan jumlah kelimpahan ragi pada nira yang digunakan, karena ragi akan mengalami suksesi jika substratnya mengandung asam. Suksesi adalah pergantian jenis mikroba sejalan dengan bertambahnya waktu fermentasi. Proses fermentasi pada nira dapat berlangsung dalam hitungan jam. Mikroba yang berkembang selanjutnya adalah mikroba yang membentuk asam asetat. Peristiwa perubahan cita rasa nira karena kehadiran bakteri, ragi dan asam laktat ini disebut fermentasi.

Nira merupakan cairan manis yang mengucur dari tandan kelapa atau pun aren. Menurut Setyamidjaja (1993) dalam Lingga, (2008), komposisi kandungan nira segar tiap $100 \mathrm{ml}$ dengan berat jenis 1,058-1,077 gram pada $29^{\circ} \mathrm{C}$. Nira yang belum difermentasi menjadi tuak pada dasarnya mengandung sejumlah mikroba baik berupa ragi maupun bakteri. Mikroba dalam nira ini berasal dari tandan maupun udara bebas ketika proses penyadapan berlangsung. Untuk kualitas organoleptik tuak sendiri bergantung pada ramuan yang ditambahkan, tuak yang dihasilkan dapat berasa sedikit manis, agak masam atau pahit, dengan bau yang tajam dan warna yang sangat keruh (Wikipedia, 2010).

\section{MATERI DAN METODE}

Tipe penelitian ini adalah penelitian eksperimen yang dilaksanakan di Laboratorium Biologi Dasar FKIP Unpatti pada bulan Juni 2011 dengan subjek penelitian adalah nira arenga pinnata sebanyak 7,2 liter, untuk 3 kali pengulangan pada masing-masing waktu fermentasi. Variabel yang digunakan adalah variabel bebas yaitu lama fermentasi ( 0 jam, 5 jam, 10 jam dan 15 jam) dan dua variabel terikat yaitu jumlah koloni ragi dan bakteri kualitas organoleptik tuak dengan indikator warna, aroma dan rasa.

Alat yang digunakan dalam penelitian ini antara lain a) Autoklaf; b) Beker Gelas; c) Gelas Ukur; d) Pipet dan Mikro pipet; e) Cawan Petri; f) Tabung Reaksi; g) Rak Tabung Reaksi; h) Inkubator; i) Erlenmeyer; j) Oven; k) Batang penyebar/Drygolski; l) 
Lup; m) Botol Sampel; n) Batang Pengaduk; o) Hot Plate; p)Timbangan Analitik; q) Bunsen; sedangkan bahan yang dibutuhkan antara lain: a) Nira Arenga pinnata; b) Medium cair berupa larutan garam fisiologis; c) Medium Padat berupa Media NA dan PDA; d) Aquades; e) Alkohol 95\%; f) Kertas label; g) Kapas; h) Alumunium foil; i) Kertas coklat; j) Benang wol; k) Spirtus. Penelitian dilakukan dengan beberapa tahapan yaitu tahapan persiapan alat bahan, tahapan pembuatan media dan sterilisasi, tahapan pengambilan sampel, uji organoleptik, tahapan pengenceran, tahapan inokulasi, inkubasi dan perhitungan koloni mikroba.

Data yang diperoleh kemudian dianalisis menggunakan teknik analisa deskriptif yaitu berupa persentase hasil perhitungan jumlah koloni. Untuk mengetahui kelimpahan koloni yang tumbuh dapat dihitung dengan cara:
Kelimpahan koloni $=$

Jumlah koloni $x \frac{1}{\text { volume inokulum } x \text { pengenceran }}$ (Black, 2005).

Pada uji organoleptik, data dianalisis menggunakan uji hedonik yang ditabulasikan dalam suatu tabel.

\section{HASIL DAN PEMBAHASAN}

Kelimpahan Mikroba Berdasarkan Lama Fermentasi

Kelimpahan mikroba pada nira aren dikultivasi pada media PDA untuk mengamati jamur dan media NA untuk mengamati mikroba, dengan selisih waktu 5 jam saat fermentasi dari 0 jam sampai 15 jam, dan dapat dilihat pada tabel 1 .

Tabel 1. Kelimpahan Mikroba Nira Aren Selama Fermentasi Pada Media PDA dan NA

\begin{tabular}{lccc}
\hline Jenis Media & $\begin{array}{c}\text { Lama Fermentasi } \\
\text { (Jam) }\end{array}$ & $\begin{array}{c}\text { Jumlah Koloni } \\
\text { (CFU) }\end{array}$ & Log Jumlah Koloni \\
\hline \multirow{3}{*}{ PDA } & 0 Jam & $48,8 \times 106$ & 7,69 \\
& 5 Jam & $27,1 \times 106$ & 7,43 \\
& 10 Jam & $19,2 \times 106$ & 7,28 \\
& 15 Jam & $12,08 \times 106$ & 7,08 \\
NA & 0 Jam & $37,0 \times 106$ & 7,57 \\
& 5 Jam & $24,6 \times 106$ & 7,39 \\
& 10 Jam & $21,0 \times 106$ & 7,32 \\
\hline
\end{tabular}

Tabel 2. Hasil Uji Organoleptik Kualitas Nira Aren Selama Proses Fermentasi pada 15 Panelis Terlatih.

\begin{tabular}{cccc}
\hline $\begin{array}{c}\text { Indikator yang } \\
\text { Diuji }\end{array}$ & $\begin{array}{c}\text { Lama } \\
\text { Fermentasi } \\
\text { (Jam) }\end{array}$ & $\begin{array}{c}\text { Rata-rata } \\
\text { Penilaian }\end{array}$ & Keterangan \\
\hline \multirow{3}{*}{ Warna } & $0 \mathrm{Jam}$ & 3 & Putih \\
& $5 \mathrm{Jam}$ & 3 & Putih \\
$10 \mathrm{Jam}$ & 3 & Putih \\
& $15 \mathrm{Jam}$ & 3 & Putih \\
\multirow{4}{*}{ Aroma } & $0 \mathrm{Jam}$ & 3 & Khas Tuak \\
& $5 \mathrm{Jam}$ & 3 & Khas Tuak \\
& $10 \mathrm{Jam}$ & 3 & Bau Tengik \\
\multirow{4}{*}{ Rasa } & $15 \mathrm{Jam}$ & 4 & Bau Alkohol \\
& 0 Jam & 4 & Manis \\
& $5 \mathrm{Jam}$ & 3 & Agak Asam \\
& $10 \mathrm{Jam}$ & 2 & Asam \\
& $15 \mathrm{Jam}$ & 2 & Asam \\
\hline
\end{tabular}




\section{Kualitas Organoleptik Tuak}

Pada uji organoleptik, digunakan panelis sebanyak 15 orang dengan waktu fermentasi yang sama, yakni 0 jam, 5 jam, 10 jam dan 15 jam. Pada Tabel 2, ditampilkan hasil rata-rata penilaian dari para panelis.

Berdasarkan hasil penelitian, seperti tertera pada tabel 1 kelimpahan mikroba pada nira sangat dipengaruhi oleh waktu fermentasi. Pada awal fermentasi 0 jam, kehadiran ragi lebih dominan, yang nampak pada media PDA jika dibandingkan dengan bakteri pada media NA. Ragi memiliki kelimpahan lebih besar dibandingkan dengan bakteri pada waktu awal fermentasi ini disebabkan oleh kandungan sukrosa yang terdapat pada nira sehingga rasa nira menjadi manis (Kusumanto, 2010) sama seperti hasil penelitian yang terlampir pada uji kualitas organoleptik. Selanjutnya, Kusumanto (2010) menjelaskan bahwa ragi pada nira ini akan memanfaatkan sukrosa melalui proses enzimatis dan mengubahnya menjadi etanol. Kecepatan fermentasi yang terjadi pada nira akan menyebabkan kadar gula menurun, karena sebagian gula dirombak oleh enzim yang dihasilkan dari proses fermentasi menjadi asam dan alkohol. Kejadian ini menyebabkan nira aren menjadi masam (kecut) dan sedikit pahit.

Pada hasil uji kualitas organoleptik, aroma pada nira yang difermentasi menjadi tuak pada 3 perlakuan pertama memiliki kualitas yang sama namun mengalami perubahan pada 15 jam terakhir karena aktifitas mikroba. Hal ini sejalan dengan hasil penelitian Mahulette (2009a) tentang aktifitas fermentatif mikroba yang mengubah karbohidrat menjadi alkohol, asam dan $\mathrm{CO}_{2}$. Mikroba proteolitik menghasilkan bau busuk dengan memecah protein dan komponen nitrogen, sedangkan mikroba lipolitik memecah dan menghidrolisa lemak dan, fosfolipid sehingga menghasilkan bau tengik (Al-Khalik, 2011). Hal ini jelas terlihat pada hasil fermentasi setelah 10 jam. Bila alkohol dan asam yang dihasilkan oleh mikroba fermentatif, cukup tinggi maka akan menekan mikroba proteolitik dan mikroba lipolitik. Aktifitas mikroba yang memanfaatkan sukrosa dengan mengaktifkan enzim lipase sebagai katalisator esterifikasi dari alkohol dan asam organik (Al-Khalik, 2011). Jadi, pada tuak yang difermentasi diketahui bahwa mikroba proteolitik dan lipolitik tidak berkembang dengan baik karena konsentrasi alkohol dan asam yang lebih tinggi, sehingga aroma yang lebih dominan adalah aroma alkohol yang agak asam karena mengandung senyawa volatile.

Indikator rasa pada perlakuan kontrol (0 jam), nira memiliki rasa yang manis disebabkan kandungan sukrosanya yang belum melalui proses fermentasi. Aktifitas mikroba belum terjadi sehingga indikator rasa pada nira masih terjaga keasliannya. Perubahan cukup signifikan terjadi pada waktu fermentasi setelah 15 jam, yakni rasa tuak berubah menjadi asam. Hal ini terkait dengan peran mikroba fermentatif oleh mikroba asam laktat. Mikroba ini menghasilkan asam asetat yang dioksidasi dari etanol (Mahulette, 2009a).

Warna dari nira menjadi tuak tidak mengalami perubahan. Hal ini terlihat sejak awal fermentasi hingga selesai, tetap sama yaitu berwarna putih. Kebanyakan tuak yang mengalami perubahan warna disebabkan adanya bahan pengawet. Seperti yang diuraikan pada hasil penelitian Rindengan, et al. (2006), mutu nira kelapa yang diawetkan dengan sabut kelapa dapat bertahan lebih dari 3 jam setelah penyadapan, warnanya menjadi kecokelatan, sehingga memberikan warna khas alami pada produk palm wine. Hal ini disebabkan karena sumber alami senyawa tanin adalah sabut kelapa yang terdiri dari debu sabut sekitar 70\% (Banzon dan Velasco, 1982), dan mengandung tanin berkisar 8-13\% (Francia, et al, 1973 \& Banzon dan Velasco, 1982 dalam Rindengan et al, 2006).

\section{KESIMPULAN}

Kelimpahan ragi lebih banyak terdapat pada awal fermentasi 0 - 5 jam dengan jumlah $27,1 \times 10^{6}-48,8 \times 10^{6}$, sedangkan jumlah bakteri lebih banyak dari ragi pada waktu fermentasi 10 jam yaitu $21,0 \times 10^{6}$, dan setelah 15 jam, jumlah kelimpahan ragi dan bakteri semakin berkurang karena mengalami suksesi dengan jumlah ragi 12,8 x $10^{6}$ dan jumlah bakteri $12,3 \times 10^{6}$. Hasil uji kualitas organoleptik tuak, pada indikator 
warna tidak mengalami perubahan sedangkan indikator rasa yang terbaik terdapat pada waktu fermentasi 0 jam, dan indikator aroma yang terbaik pada waktu fermentasi 15 jam. Disarankan kepada peneliti yang perlu dilakukan penelitian lanjutan tentang identifikasi jenis mikroba pada nira aren.

\section{DAFTAR PUSTAKA}

Al-Khalik, Z. Ns. 2011. Enzim Lipase. (http://swiss8910.blogspot.com/).

Diakses, 11 Agustus 2011.

Anonim, 2010. Jamur dan Klasifikasinya. (http://kambing.ui.ac.id) Diakses, 09 Febuary 2011.

Anonim, 2011. Inokulasi Dan Peremajaan Biakan Dalam Media Padat Dan Cair. (http://framesti.wordpress.com). Diakses, 15 Januari 2011.

Black, J.G. 2005. Microbiology, Principles and Exploration. Jhon Wiley and Son. Ltd.

Campbell, N.A, Reece, JB, Mitchel, LG. 2002. Biologi. Jilid I. Jakarta: Erlangga

Dwijoseputro. 2003. Dasar-dasar Mikrobiologi. Jakarta: Djambatan.

Hassan, Z.H. 2008. Isolasi Lactobacillus, Bakteri Asam Laktat dari Feses dan Organ Saluran Pencernaan Ayam. (http://peternakan.litbang.deptan.go.id).

Diakses, 20 Oktober 2009.

Harijoto dan Widjowati, 1997. Metode Pengambilan Contoh Air dan Pemeriksaan Bakteriologi Air. Departemen Kesehatan RI. Yogyakarta.

Hidayati, N. 2009. Manfaat Pohon Aren.( http://niahidayati.net). Diakses, 20 Agustus 2010.

Kusumanto, D. 2010. Mencari Cara Pengawetan Alami Nira Aren Untuk Produksi Gula Organik. (http://arenfoundation.wordpress.com). Diakses, 11 Agustus 2011.

Lingga. A. 2008. Pengaruh Perbedaan Lama Penyimpanan Nira Terhadap Kadar
Alkohol Yang Dihasilkan. (http://www.scribd.com). Diakses, 20 Oktober 2009.

Mahulette, F. 2009a. Isolasi dan Penentuan Mikroorganisme Dominan Pada Fermentasi Tradisional Arak Ambon Serta Optimasi Pembuatannya Secara Fermentasi Terkontrol. (Tesis, Tidak Dipublikasikan). Institut Teknologi Bandung.

Mahulette, F. 2009b. Masak Sopi. (http://hiin.facebook.com). Diakses, 20 Oktober 2009.

Nailoa, E. 2008. Mikrobia Amilolitik Pada Nira dan Laru Dari Pulau Timor Nusa. Jakarta. (http://www.pdfchaser.com). Diakses, 11 Februari 2011.

Nurmiati, dkk. 2006. Kajian Fisiologis dan Perkembangan Bakteri-bakteri Asam Laktat Pada Beberapa Medium Cair Dalam Pengadaan Bank Mikroba. http://repository.unand.ac.id). Diakses, 12 Januari 2011.

Rahayu, W.P. 2001. Penuntun Praktikum Penilaian Organoleptik. Bogor: Institut Pertanian Bogor.

Ridwan. 2008. Pengolahan Produk. (http://tekhnologi-hasil-

pertanian.blogspot.com). Diakses, 25 Febuari 2011.

Rindengan, B. et al., 2006. Pengaruh Sabut Kelapa Terhadap Kualitas Nira Aren dan Palm Wine. Manado: Balai Penelitian Tanaman Kelapa dan Palma Lain Mapanget.

Soeseno, S. 1993. Bertanam Aren. Jakarta: Penebar Swadaya.

Tjitrosoepomo, G. 2007. Taksonomi Tumbuhan Spermatophyta. Yogyakarta: Gajah Mada University Press.

Wikipedia. $2009 . \quad$ Lactobacillus. (http://id.wikipedia.org). Diakses, 20 Oktober 2010.

2010. Aren Indonesia.

(http://id.wikipedia.org). Diakses, 20

Agustus 2010. 